\title{
SPATIAL DISTRIBUTION OF MANGROVE ECOSYSTEM IN CONSERVATION AREA OF TELUK KELUMPANG NATURE RESERVE
}

\author{
Mufidah Asyari, Udiansyah \\ Lecturers at Forestry Faculty, Lambung Mangkurat University, Banjarbaru, South Kalimantan \\ Email: mufie.ikhsan@unlam.ac.id
}

\begin{abstract}
Mangrove forest area of $98,494.6$ ha $(72.86 \%)$ is distributed in Kotabaru Regency. Based on the forest status, the mangrove forest consists of a nature reserve zone covering an area of $66,487.5$ ha $(67.50 \%)$, production forests $3,510.4$ ha $(3.57 \%)$, and area for other uses $28,496.7$ ha $(28.93 \%)$ (BKSDA, 2008 the Ministry of Forestry, 2009; Sirang et al., 2010). The purpose of this study was to find out the spatial distribution of mangrove ecosystem in Teluk Kelumpang Nature Reserve. The study was conducted using a remote sensing technology (Landsat 7 ETM + 2012 (Path/Row: 117/063) to obtain data of the extent, and the distribution of mangrove forest species in Teluk Kelumpang nature reserve. The measurement of mangrove vegetation was to find out the potency and characteristics of mangrove forest stands. The results showed that the potential vegetation in the area of Teluk Kelumpang nature reserve was $R$. apiculata, $R$. mucronata and $B$. gymnorhiza. Teluk Kelumpang nature reserve is divided into two zones. The first zone is proximal zone (50 m - $100 \mathrm{~m}$ from coastline), a zone dominated by $R$. apiculata and $R$. mucronata plants. The second is middle zone, a mixed zone comprising B. gymnorhiza, $X$. granatum, $C$. decandra, and $N$. fruticans, with the area of $>100 m-500 m$ from the river line and coastline.
\end{abstract}

Keywords: mangrove forest, nature reserve, spatial distribution

\section{INTRODUCTION}

Teluk Kelumpang Nature Reserve is located in Kotabaru Regency, South Kalimantan Province, defined by the Decree of the Minister of Forestry No. 435/MenhutII/2009, on July 23,2009 , with an area of \pm $29,925.74$ ha. Teluk Kelumpang is included as the mangrove forest conservation zone. It is $30.38 \%$ of the total area of mangrove forests in Kotabaru Regency. About $45.01 \%$ of the mangrove forests is part of the forest conservation area (Conservation Center of Natural Resources, 2008; the Ministry of Forestry, 2009).

Mangrove forest is a natural resource in coastal area with the functions for production, protection and nature conservation. Mangrove forest ecosystem is very unique because it serves as the interface between the terrestrial and marine ecosystems. Its role is very huge for people living in coastal areas, in terms of both ecology and economy (Bengen, 2004; BPDAS Barito, 2006; Anwar \& Gunawan, 2007; Harahab, 2010).

The existence of mangrove forests is essential for life because it can provide functions and benefits directly and indirectly to living creatures (Sathirathai and Barbier, 2001; Tepu, 2004). Mangrove forests greatly support social and economic development of the coastal community (Bengen, 2004; Anwar \& Gunawan, 2007; Ndenecho, 2007; Harahab, 2010). There are some examples of mangrove forest utilizations by communities, among others, raw materials for charcoal (Bengen, 2004; Tepu, 2004; Saunders et al., 2007), organic materials, sources of food, cosmetics, tanners, (wood from mangrove species of langadai and mirih), pharmaceuticals, like the leaves of $B$. sexangula for inhibiting tumor, and $C$. tagal and $X$. mollucensis for toothache, (Alongi, 2002; Sofia, 2004; Rönnbäck et al., 2007; Tarin, 2008; Hussain and Badola. 2010), agricultural lands, plantations, and fishponds (Sremongkontip et al., 2000; Onrizal 2006; Suwargana 2008; Purwoko 2009; Sirang et al., 2010), as well as the settlement (Klemas 2009; Elsebaie and Aguib, 2013).

The distribution of mangrove forest area of $135,181.5$ ha in South Kalimantan lies in the areas for conservation, production forest, and outside the forest areas (areas for other uses) covering an area of 77,944.3 ha (57.66\%), 4,792.3 ha (3.55\%), 52,444.9 ha (38.79\%), respectively (BKSDA, 2008; Sirang, et al., 2010). The mangrove forest area of $98,494.6$ ha $(72.86 \%)$ is located in Kotabaru Regency. Based on the forest status, the nature reserve zone covers an area of 
$66,487.5$ ha $(67.50 \%)$, production forest area $3,510.4$ ha $(3.57 \%)$, and areas for other uses $28,496.7$ ha $(28,93 \%$ ) (the Ministry of Forestry, 2009).

Given the importance of these areas for the welfare of communities, the natural resources need to be managed and developed in accordance with their functions and characteristics. The utilization of mangrove forests need to be managed in a planned and sustainable manner. The planning efforts that can be applied and ensure sustainability should be in accordance with the management scheme based on the information data on the extent and condition of stands which include the species composition and distribution.

The objective of this study was to find out the spatial distribution of mangrove forest ecosystem in Teluk Kelumpang nature reserve to support the preservation of mangrove ecosystem. The particular objectives of the study were:
1. to find out the distribution of species composition in mangrove forests at Teluk Kelumpang nature reserve.

2. to identify the spatial distribution patterns of mangrove forest ecosystem in the conservation zone.

\section{MATERIALS AND METHODS}

Study Site. This study was conducted in the conservation area of mangrove forests in Teluk Kelumpang nature reserve, Kotabaru Regency, South Kalimantan. The mangrove forest has an area of $\pm 29,925.74$ ha, and is geographically located at $2^{\circ} 42^{\prime} 16^{\prime \prime}$ to $3^{\circ} 6^{\prime} 8^{\prime \prime}$ south latitude $(9,690.56 \mathrm{mU}-9,656,294 \mathrm{mU})$, and $116^{\circ} 15^{\prime}$ to $116^{\circ} 19^{\prime} 01^{\prime \prime}$ East (391.775 mT - $420.369 \mathrm{mT}), \quad$ (BKSDA, 2008). Teluk Kelumpang nature reserve is located along the coast of Teluk Kelumpang Tengah, which is $350 \mathrm{~km}$ from Banjarmasin city and $15 \mathrm{~km}$ from the capital city of Kotabaru Regency (Figure 1).

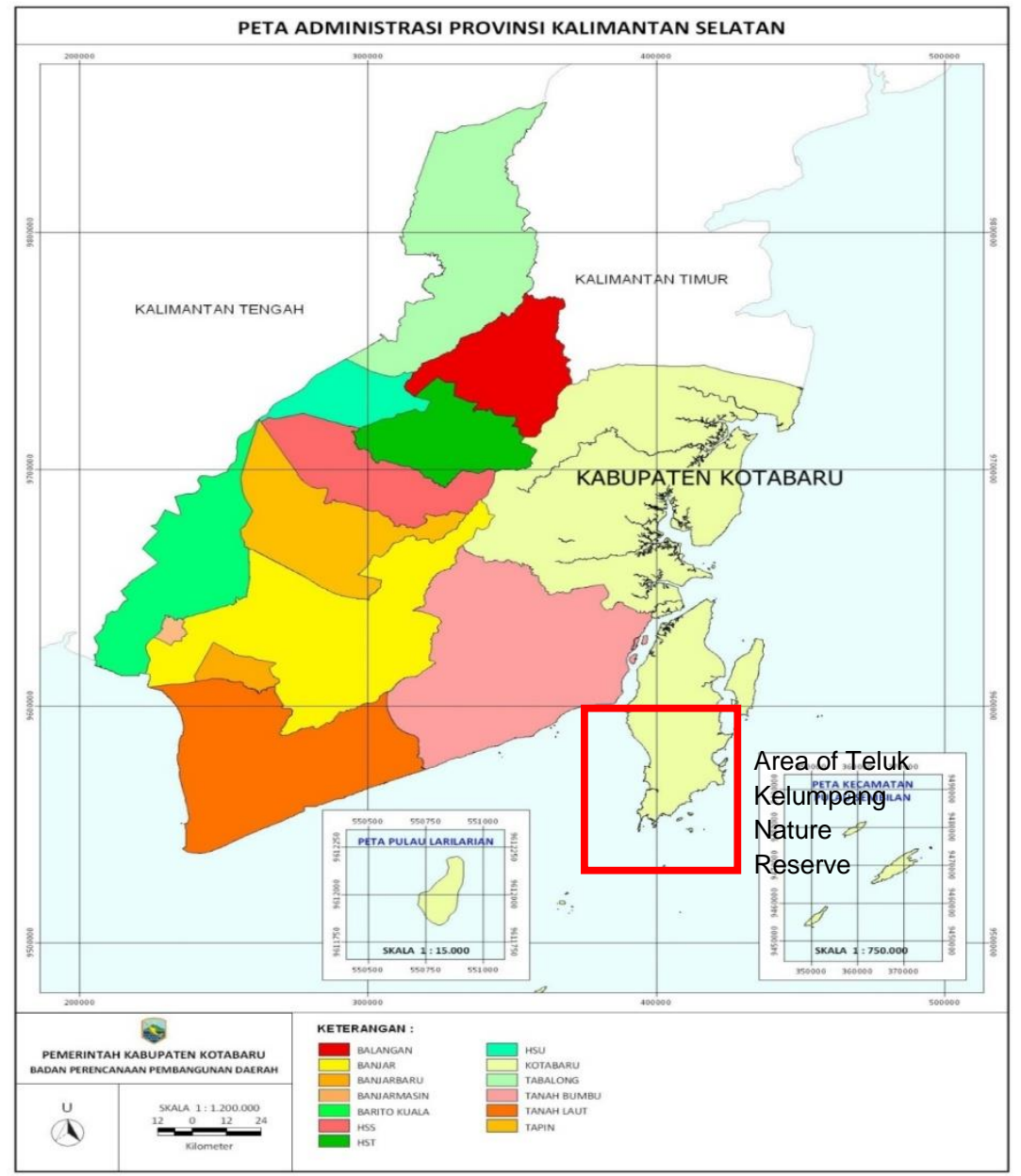

Figure 1. Study site in the conservation area of Teluk Kelumpang nature reserve

(Source: Bappeda, Kotabaru Regency, 2013) 
Materials and equipment used in this study: Landsat 7 ETM + year 2012 (Path / Row: 117/063); Rupa Bumi RBI Digital Map of South Kalimantan, 2007, Scale 1: 50,000; Map of South Kalimantan Forests. The Minister of Forestry Decree No. 435 of 2009; Software ArcView version 3.3 and ArcGis versi 9.3; Compass to determine the direction of observed plots; GPS (Global Positioning System), to determine the plot coordinates and geographical location of the study site; Clynometer to determine slopes; Measuring band/phiband to determine the tree diameter; 20 meters of meter gauge to create plots; Tally sheet for recording the data; Stationery; Floristic books to find out the types of mangrove vegetation; Tripping tools (chopper, machete, knife, scissors); and Camera for documentation.

Data Collecting Methods. The types of data required in this study were divided into two, primary and secondary data. Primary data were collected directly from the study site. The secondary data were derived from literature, journal articles, results of previous studies related to the study conducted (Sugiyono, 2009).
The primary data were obtained using a remote sensing technology to obtain data on the extent and map interpretation by reviewing the identification of Landsat 7 ETM +2012 (Path/Row: 117/063). The results of data processing showed the areas of the cover extent and species composition distribution in mangrove forests at Teluk Kelumpang nature reserve.

Data Analysis. The inventory and identification of mangrove forest species in plots included the names of tree species with their growth stages (seedling, sapling, and tree), diameter measurement of tree (to determine the diameter distribution of each species), tree height, number of each tree species and tree density at each extent.

The plots were made straight from coastline to inland. The plots were made in alternate transects along the line with a size of $10 \mathrm{~m} \times 10 \mathrm{~m}$ for the tree stage, $5 \mathrm{~m} \times 5 \mathrm{~m}$ for sapling stage, and $2 \mathrm{~m} \times 2 \mathrm{~m}$ for seedling stage, to the end line of the mangrove forest in inland. The example of lines and plots is presented in Figure 2.

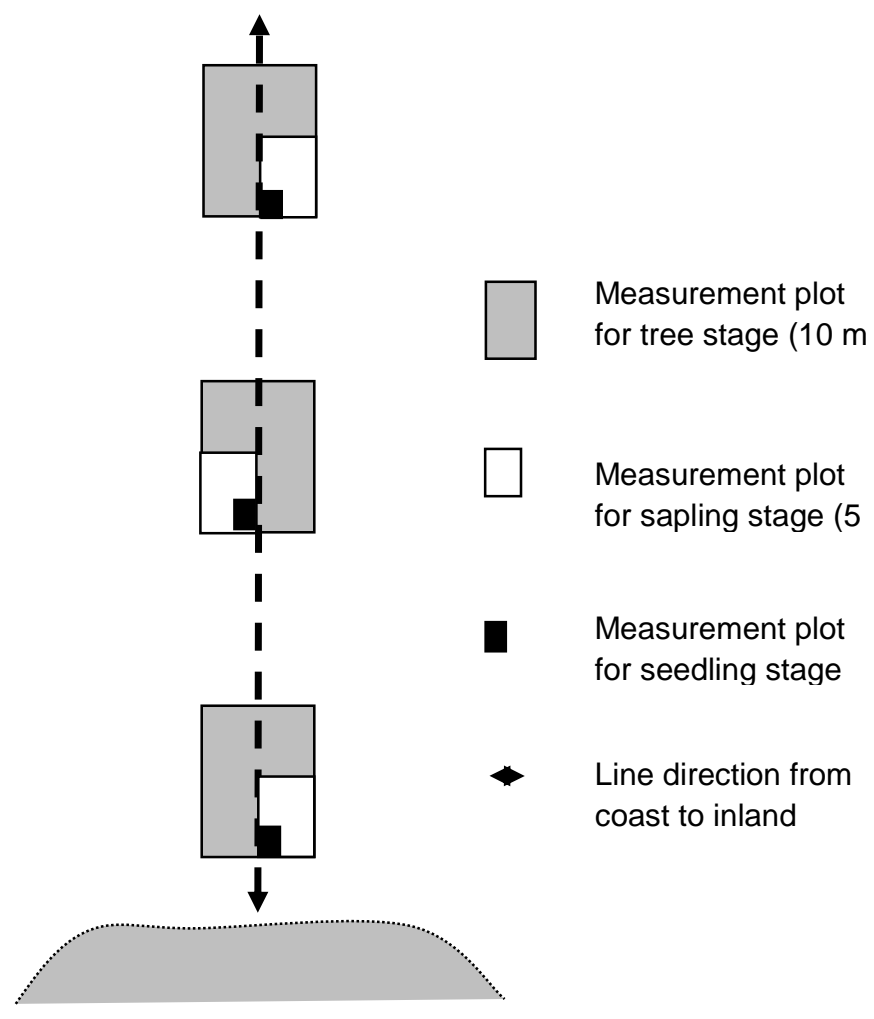

Figure 2 Example of Measurement Plots in Field 
Species distribution in the mangrove forest can be described through creating transects carried out by taking a straight line from the coast to inland.

Spatial distribution pattern is a method of mapping the distribution of mangrove forest species by natural boundaries to identify the structure of mangrove forests. The distribution of mangrove forests was carried out horizontally and vertically using class of diameter $(5 \mathrm{~cm}$ interval) and class of tree height (1 $\mathrm{m}$ interval). Meanwhile, the determination of the vertical distribution was performed visually by creating illustration of mangrove forest cross-sections in Teluk Kelumpang nature service. Data used in this analysis came from the observation and documentation in the field, with visual description, types, characteristics and condition of mangrove forests in Teluk Kelumpang nature reserve.

Horizontal spatial distribution pattern illustrated the distribution of mangrove forest species based on the physical characteristic (canopy) on the entire mangrove forest. This distribution pattern can be visualized in a map of the distribution of mangrove forest species.

\section{RESULTS AND DISCUSSION}

\section{Distribution of Mangrove Forest Species in Teluk Kelumpang Nature Reserve}

The results of identification and classification showed that Teluk Kelumpang nature reserve had an area of $\pm 29,925.74$ ha (MoF, 2009), consisting of primary mangrove forest; secondary mangrove forest; plantation; dry land agriculture; swamp shrubs; ponds and open land (BPDAS Barito, 2006; Sirang et al., 2010). The land covers were dominated by secondary mangrove forest $(41.29 \%)$ and primary mangrove forest $(27.87 \%)$ of the total Teluk Kelumpang nature reserve area.

The making of lines (transects) from coast to inland in this study was to describe the distribution of mangrove vegetation formation. The plots were made in the alternate intersects along the line with a size of $10 \mathrm{~m} \times 10 \mathrm{~m}$ for tree stage, $5 \mathrm{~m} \times 5 \mathrm{~m}$ for sapling stage, and $2 \mathrm{~m} \times 2 \mathrm{~m}$ for seedling stage. The measurement process of mangrove species is shown in Figure 3.

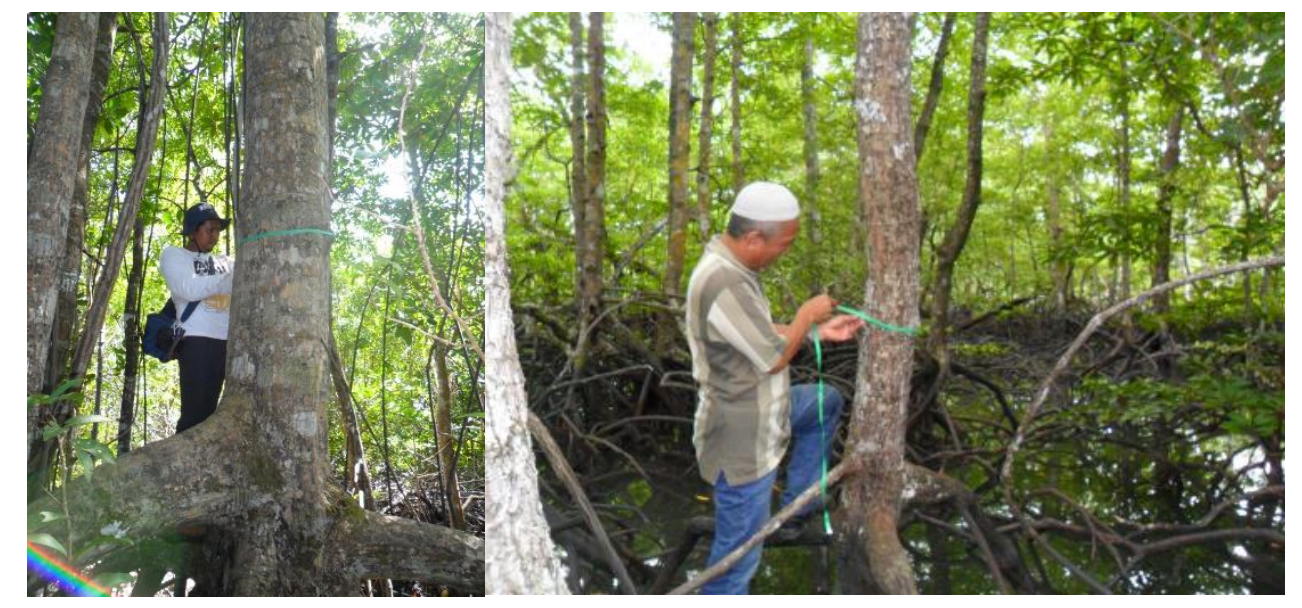

Figure 3. Process of mangrove vegetation measurement in Teluk Kelumpang nature reserve

Succession pattern of mangrove forest in Teluk Kelumpang nature reserve was that the dominant species composition was unchanged at regeneration stage until tree stage, such as mangrove species (Rhizaphora apiculata, Rhizaphora mucronata) and langadai (Bruguiera gymnorhiza). The three vegetation species located on the front served as coastal defense from open sea, which contained a lot of mud potential for the development of these three vegetation species and other vegetation species. It was also found out in Baluran National Park; that the distribution of mangrove vegetation was dominated homogeneously and alternately by Rhizaphora spp., Bruguiera gymnorhiza, Sonneratia alba, and Ceriops tagal (Sudjarmaji, 2003).

Among the three dominant tree species, $R$. apiculata was the species with the average diameter $27 \mathrm{~cm}$; the smallest $10 \mathrm{~cm}$ and the largest $49 \mathrm{~cm}$. Overall, the mangrove forest vegetation at all stages of growth had 
the smallest diameter $12 \mathrm{~cm}$ and the largest $57 \mathrm{~cm}$. The diameter distribution of mangrove forest with more trees was $<18 \mathrm{~cm}$ while the diameter distribution of mangrove forest vegetation with fewest number of trees was > $37 \mathrm{~cm}$.

$R$. apiculata and $R$. mucronata are mostly found in many locations in primary and secondary mangrove forests. The primary mangrove forest is widely spread at the coastal bays in Kelumpang Tengah Subdistrict while the secondary mangrove forest in Kelumpang Hulu Sub-district, and they dominate the regions. The mangrove ecosystems are dominated by mangrove tree species (Rhizophora spp), and typical shrubs that can grow in salty or brackish waters (Supriharyono, 2000; Santoso, 2002; Bengen, 2004; Sofia, 2004; Onrizal, 2008).

\section{Spatial Distribution of Mangrove Forests in Teluk Kelumpang Nature Reserve}

Spatial distribution pattern can provide information on vegetation composition at the transect lines illustrated by horizontal crosssection. The cross-section can horizontally describe the distribution of the vegetation composition and establish the zonation according to the vegetation types. Species distribution of vegetation composition of mangrove forests in Teluk Kelumpang nature reserve was based on the diameter and height of trees, the distance between vegetation, and the distance of vegetation to the riverbank or coastline.

Based on observations and analysis, $R$. apiculata is a vegetation species with taproots that can grow well in wet, muddy, and sandy soil (Sudarmadji, 2003). These characteristics correspond to the ecosystem condition where $R$. apiculata, that could reach $6 \mathrm{~m}$ in height, grew in Teluk Kelumpang nature reserve. In general, the smallest tree diameter of the vegetation at all growth stages was $12 \mathrm{~cm}$ and the largest $57 \mathrm{~cm}$. The distribution of the greatest number of trees dominating Teluk Kelumpang nature reserve was the trees with a diameter of $<18 \mathrm{~cm}$. The least number of trees was the trees with larger diameter. This condition showed that the number of largediameter trees $(>37 \mathrm{~cm})$ was likely to decline when their diameter increased. This was due to illegal logging in some parts of Teluk Kelumpang nature reserve. Moreover, smallsized vegetation competed with each other during the growth development, and the vegetation that unsuccessfully grew larger would be eliminated (Sudarmadji, 2003). The distribution is presented in Figure 4.

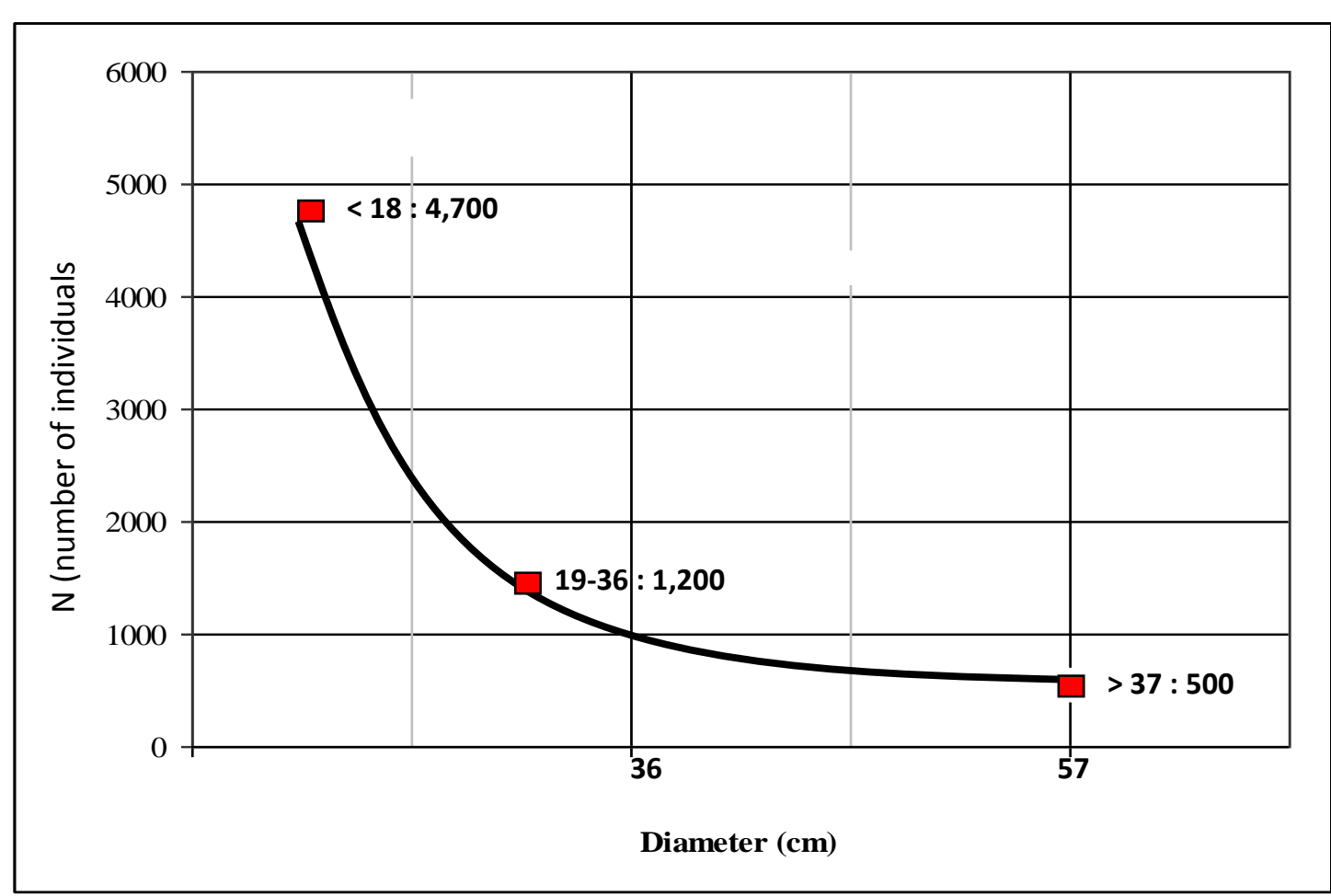

Figure 4. Diameter distribution of mangrove vegetation in Teluk Kelumpang nature reserve 
This spatial distribution illustrates the vegetation transect patterns for grouping the vegetation species forming the zonation. The mangrove forest zoning was based on the frequency of tidal inundation, the salinity level of the water inundation, and the dominant tree genera (Dahuri, 2003). Based on the observation and analysis, mangrove forest vegetation in Teluk Kelumpang nature reserve is divided into two zones: (1) proximal zone, the zone that is closest to the sea with the dominating vegetation species $R$. apiculata, $R$. mucronata, and Sonneratia alba. The distance of the zone from the coastline and riverbank is $50 \mathrm{~m}-100 \mathrm{~m}$. (2) Middle zone or mixed zone, composed of various species of vegetation such as langadai (B. gymnorhiza), mirih (Xylocarpus granatum), tingi (Ceriops decandra), and Nypha fruticans. The distance of the zone from the river line and coastline is $>100 \mathrm{~m}$ to $500 \mathrm{~m}$. The species in the mixed zone was Langadai (B. gymnorhiza) and sometimes mixed with tingi (C. decandra), and mirih ( $X$. granatum). The zonation in Teluk Kelumpang nature reserve was in accordance with Bengen's statement (2004), that the species of vegetation dominating the area around the coastline and riverbank are $R$. apiculata and $R$. mucronata. Further into the inland were places that were a bit dry dominated by mixed zonation, like $B$. gymnorhiza, S. caseolaris, and $X$. granatum. The vertical zonation is presented in Figure 5.

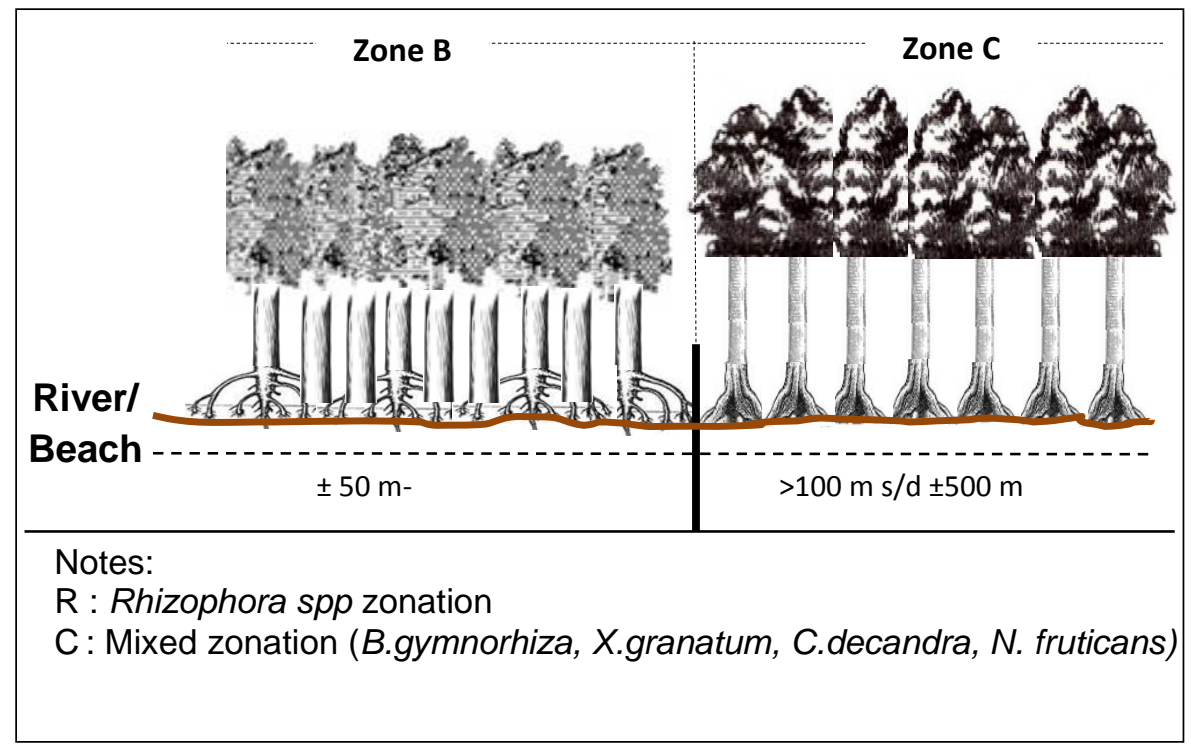

Figure 5. Vertical cross-section of mangrove forest zonation in Teluk Kelumpang nature reserve

\section{CONCLUSIONS}

Potential vegetation species in the area of Teluk Kelumpang nature reserve are $R$. apiculata, $R$. mucronata and $B$. gymnorhiza. The mangrove forests in Teluk Kelumpang nature reserve are divided into two zonations. The first zonation is proximal zone, the zone dominated by $R$. apiculata and $R$. mucronata species, with the zonation of 50 $\mathrm{m}-100 \mathrm{~m}$ from the coastline and riverbank. The second zonation is middle zone, the mixed zone consisting of $B$. gymnorhiza, $X$. granatum, $C$. decandra, and $N$. fruticans, with the zonation of $>100 \mathrm{~m}-500 \mathrm{~m}$ from of the river line and coastline.

\section{REFERENCES}

Alongi, D. M. 2002. Present State and Future of the World's Mangrove Forest. Environmental Conservation. 29 (3): 331 - 349.

Bengen, D.G. (2000). Sinopsis of Coastal Natural Resource Ecosystem. Center for Coastal and Marine Resources Studies - Bogor Agricultural University. Bogor.

BKSDA (2008). Conservation area in South Kalimantan. Center for the Conservation of Natural Resources, Regional V, South Kalimantan. Banjarbaru. pp. 6-12. (2009). Evaluation of Teluk Kelumpang Nature Reserve, Kotabaru Regency, South 
Kalimantan. Collaborative activities for Teluk Kelumpang Nature Reserve Protection between BKSDA South Kalimantan and PT. Arutmin Indonesia. Banjarbaru. (2012). Identification of Flora and Fauna in Fresh Water of Teluk Kelumpang Nature Reserve, Kotabaru Regency. Collaborative activities for Teluk Kelumpang Nature Reserve Protection between BKSDA South Kalimantan and PT. Arutmin Indonesia. Banjarbaru.

BP DAS Barito (2006). Mangrove Forest Inventory and Identification. Center for Barito Watershed Management. Forestry Department. Banjarbaru.

Dahuri, R. (2003). Marine Biodiversity: Indonesian Sustainable Development Asset. Publisher Gramedia Pustaka Utama. Jakarta.

Dirjen RPLS. 2005. Mangrove Inventory and Identification Guidelines. Directorate General of Land Rehabilitation and Social Forestry. Forestry Department. Jakarta.

Elsebaie, I.H., and Aguib, A.S.H. (2013). The Role of Remote Sensing and GIS for Locating Suitable Mangrove Plantation Sites along the Southern Saudi. International Journal of Geosciences 4: 471- 479.

Forestry Ministry of the Republic of Indonesia (2009). Decree Number: 435/Menhut-II/2009, regarding the designation of forest areas in South Kalimantan Province. Jakarta.

Mackinnon, K., Hatta, Gt. M., Halim, H. and Mangalik, A. (2000). Kalimantan Ecology (Book III). Prenhallindo. Jakarta.

Law of the Republic of Indonesia (1999). Law Number 41 Year 1999 on Forestry, September 30, 1999. The Minister of State Secretary. Jakarta.

Onrizal (2006). Mangrove Forests: How to Use Them Sustainably. Warta Konservasi Lahan Basah 14 (3): 1418.

Rönnbäck, P. dan Primavera, J.H. (2000). Illuminating the Need for Ecological Knowledge in Economic Valuation of Mangroves Under Different Management Regimes - a Critique. Ecological Economics 35: 135 141.

Sirang, K., Kadir, S. and Rudianto (2010). Updating the data of mangrove forests in South Kalimantan Province 2010. Forestry Program, Palangkaraya University. Tropika Journal 6 (1) ISSN: 1693-7643.

Sofia, Y. (2004). Mangrove Ecology. Forestry Department. Samarinda.

Sremongkontip, S., Hussin, Y.A., Groenindijk, L. (2000). Detecting Changes in The Mangrove Forests of Southern Thailand Using Remotely Sensed Data and GIS. International Archives of Photogrammetry and Remote Sensing. 33(B7): $567-574$.

Sudarmadji (2003). Mangrove Forest Profile of Baluran National Park in East Java. Jurnal Berkala Penelitian Hayati $9: 45-48$.

(2009). Distribution and Extent of Mangrove Forests in Baluran National Park, East Java.. Jurnal Biotika 7. 1 : 15-19. 